\title{
Field Resistance to Verticillium Wilt in Selected Olive Cultivars Grown in Two Naturally Infested Soils
}

C. Trapero, Departamento de Agronomía, Universidad de Córdoba, Campus de Rabanales, Edif. C4, 14071, Córdoba, Spain; N. Serrano, O. Arquero, and C. Del Río, IFAPA Centro Alameda del Obispo, Apdo. 3092, 14080, Córdoba, Spain; and A. Trapero and F. J. López-Escudero, Departamento de Agronomía. Universidad de Córdoba, Campus de Rabanales, Edif. C4, 14071, Córdoba, Spain

\begin{abstract}
Trapero, C., Serrano, N., Arquero, O., Del Río, C., Trapero, A., and López-Escudero, F. J. 2013. Field resistance to Verticillium wilt in selected olive cultivars grown in two naturally infested soils. Plant Dis. 97:668-674.

The resistance of 11 olive cultivars to Verticillium dahliae was assessed in two experimental field trials. One-year-old rooted olive cuttings from the World Olive Germplasm Bank (IFAPA research center, Córdoba, Spain) were planted in a heavily infested field in Utrera (Sevilla province) and in a moderately infested field in Andújar (Jaén province) of southern Spain. Plants were assessed for Verticillium wilt resistance during 22 months based on disease severity and tree growth. Severe disease symptoms were observed 6 months after planting in both trials. Twenty months after planting in the heavily infested soil, $V$. dahliae had killed nearly all of the trees of 'Bodoquera', 'Cornicabra', 'Manza-

nilla de Sevilla', and 'Picual', demonstrating the elevated risk of planting susceptible cultivars in a soil heavily infested with $V$. dahliae. 'Arbequina', 'Koroneiki', 'Sevillenca', and especially 'Frantoio', 'Empeltre', and 'Changlot Real' showed a high level of disease resistance. However, all of them were affected by the disease. Although the field results confirmed the level of resistance previously obtained for these olive genotypes under controlled conditions, there were some discrepancies. This information will be useful in managing the disease and also in selecting new cultivars for the breeding of Verticillium wilt resistance.
\end{abstract}

Verticillium wilt of olive (Olea europaea L.) (VWO), caused by Verticillium dahliae Kleb., is the most serious disease affecting this crop in all areas of the Mediterranean basin where it is cultivated, and particularly in the Andalusian region of southern Spain. More than 1.5 million ha of olive orchards are grown in this region, where the pathogen causes large economic losses due to the intensive defoliation and die-back of shoots of infected olive trees. Affected olive trees are usually killed by the pathogen, particularly if the infection is caused by highly virulent isolates (defoliating pathotypes; 31,32). Recent surveys conducted in Verticillium wiltaffected orchards located in the Guadalquivir Valley in Andalucía revealed a mean disease incidence of 12,22 , and $24 \%$ in three large olive-producing provinces: Sevilla, Córdoba, and Jaén, respectively $(31,32)$.

To achieve control of this disease, it is necessary to apply an integrated strategy, in which all available control measures must be implemented, because none of them are sufficiently effective when applied individually $(23,31)$. Among integrated disease management strategies, the use of resistant cultivars is likely the most economically effective and environmentally friendly measure $(1,8,15,16,19,45)$. Research in resistance to Verticillium wilt of olive was started in 1994 by the Department of Agronomy of the University of Córdoba (Spain) through a program to evaluate the resistance in olive cultivars of the World Olive Germplasm Bank located at the IFAPA research center (Andalusian Institute for Agricultural Research), Córdoba, Spain (2). This collection of olive germplasm contains more than 400 authenticated cultivars.

During the last 15 years, more than 140 domestic and foreign cultivars with interesting agronomical and commercial characteristics have been evaluated for Verticillium wilt resistance under controlled conditions. Moderate levels of resistance were found in

Corresponding author: C. Trapero, E-mail: g32trrac@uco.es

Accepted for publication 28 November 2012.

http://dx.doi.org/10.1094/PDIS-07-12-0654-RE

(C) 2013 The American Phytopathological Society
'Changlot Real', 'Empeltre', and 'Frantoio' (29,30,35). These cultivars are able to restrict the colonization of plant tissues by the pathogen, thus delaying progression of the disease, increasing recovery of infected plants, and reducing the percentage of dead plants compared with susceptible cultivars $(31,36)$. Moderately resistant cultivars are desired by farmers to replace dead or severely damaged trees.

Most of the olive cultivars evaluated by artificial inoculations were susceptible or extremely susceptible to the pathogen, however, including major Spanish cultivars 'Picual', 'Hojiblanca', 'Cornicabra', and 'Arbequina'; and major cultivars from other countries, such as 'Ayvalik', 'Coratina' 'Megaritiki', and 'Meski'. Susceptibility was particularly pronounced when highly virulent isolates of $V$. dahliae were used for inoculation. The level of resistance of many of the cultivars evaluated under controlled conditions was evaluated in field trials in either experimental or commercial olive orchards planted in infested soil $(9,26,31,41,45)$ but results were variable and, at times, inconsistent with the controlled studies $(14,28,31,45)$. In many studies, important parameters such as history of previous crops in the infested plots, crop management, climatic parameters, soil type, and inoculum potential of the pathogen in soil (inoculum density and virulence of the isolates) were unknown or not reported $(31,45)$.

Traditionally, olive cultivars have been clonally propagated $(5,20,39)$ but there is still confusion about cultivars being true to type. Synonymies (the same cultivar with different names) and homonyms (different cultivars with the same name) exist among and within olive-growing countries (22), which makes the correct identification of olive cultivars for scientific assessments difficult. The aim of the present study was to assess the level of resistance of authenticated olive cultivars to $V$. dahliae in soils naturally infested with the pathogen and subjected to different disease pressures (which is determined by inoculum density, type of pathogen strain, previous history of susceptible hosts, and environmental conditions for disease development).

\section{Materials and Methods}

Plant material. One-year-old rooted cuttings of 11 major olive cultivars from Spain and other countries were used in both trials 
(Tables 1 and 2). The reaction of the cultivars to artificial inoculation with $V$. dahliae was previously identified $(29,30,35)$. Cuttings were obtained from agronomically, morphologically, and genetically authenticated olive mother plants from the World Olive Germplasm Bank in Córdoba, and were identified by a register number (Tables 1 and 2).

Plants were propagated by rooting of soft-wood cuttings under mist (12). Small, 15-cm-long cuttings with four to six internodes and bearing two or three pairs of leaves were taken from shoots of olive mother plants in active vegetative growth. Cuttings were dipped for $5 \mathrm{~s}$ in a $4 \mathrm{~g} /$ liter solution of indol-3-butyric acid, dissolved in a $40 \%$ ethanol solution. Cuttings were then inserted up to $4 \mathrm{~cm}$ deep in perlite on propagation benches that were maintained at 20 to $25^{\circ} \mathrm{C}$, with high relative humidity provided by intermittent mist. After 2 months, rooted cuttings were transplanted in small peat pots for 3 weeks until a pair of buds had sprouted. Then, plants were transplanted to 3 -liter plastic bags containing $40 \%$ peat, $60 \%$ silt, and a slow-release fertilizer (osmocote $20-10-15$ per bag). Bags were placed in a lath house for 5 months. At this time, all shoots were pruned, with the exception of the most vigorous and straight one. Lateral branches and new shoots were pruned until plants reached a height of $1.5 \mathrm{~m}$, at which time they were planted in the field.

Experimental plots. One experimental plot was located in the municipality of Utrera (lower Guadalquivir Valley, Sevilla province of Andalucía, southern Spain) in a cultivated marsh zone. In this area, soils have been heavily infested with a highly virulent strain of $V$. dahliae (defoliating pathotype) since 1996 (6) due to the continued cropping over many years of different $V$. dahliae hosts, such as cotton, sugar beet, or other vegetable crops.

The other experimental plot was located in the municipality of Andújar (upper Guadalquivir valley, Jaén province of Andalucía, southern Spain) in a large olive production area. Soils in this area are usually moderately infested with $V$. dahliae, and the presence of the defoliating pathotype has only recently been reported in this area (25).

Mild, humid winters and warm, dry summers characterize both Mediterranean climatic areas. Utrera and Andújar climatic values

Table 1. Values of disease parameters of major olive cultivars growing in a soil highly infested with Verticillium dahliae (21 microsclerotia/g of soil) located in Utrera, Sevilla province, southern Spain

\begin{tabular}{|c|c|c|c|c|c|c|c|c|}
\hline \multirow[b]{2}{*}{ Cultivar } & \multicolumn{2}{|c|}{ Olive cultivar $^{w}$} & \multicolumn{4}{|c|}{ Disease parameters $^{x}$} & \multirow[b]{2}{*}{ Growth $^{y}$} & \multirow[b]{2}{*}{ Defol. $(\%)^{\mathrm{z}}$} \\
\hline & Reference & Origin & DI (\%) & RAUDPC (\%) & FS & $\mathbf{M}(\%)$ & & \\
\hline Cornicabra & CV F8-A16 R10 & Spain & $100 \mathrm{a}$ & $73.2 \mathrm{a}$ & $4.0 \mathrm{a}$ & $100 \mathrm{a}$ & $0.3 \mathrm{f}$ & 74 \\
\hline Bodoquera & CV F10-A12 R361 & Spain & $95.8 \mathrm{ab}$ & $65.5 \mathrm{ab}$ & $3.8 \mathrm{a}$ & $95.8 \mathrm{a}$ & $0.6 \mathrm{ef}$ & 52 \\
\hline Manzanilla de Sevilla & CV F1-A16 R1468 & Spain & $100 \mathrm{a}$ & $64.4 \mathrm{ab}$ & $3.9 \mathrm{a}$ & $91.7 \mathrm{ab}$ & $0.5 \mathrm{ef}$ & 55 \\
\hline Picual & CV F3-A1 R1470 & Spain & $100 \mathrm{a}$ & $56.8 \mathrm{ab}$ & $3.8 \mathrm{a}$ & $91.7 \mathrm{ab}$ & $1.0 \mathrm{de}$ & 69 \\
\hline Hojiblanca & CV F3-A11 R2 & Spain & $87.5 \mathrm{abc}$ & $50.3 \mathrm{~b}$ & $3.3 \mathrm{a}$ & $70.8 \mathrm{~b}$ & $0.9 \mathrm{e}$ & 84 \\
\hline Arbequina & CV F2-A16 R1469 & Spain & $83.3 a b c$ & $29.6 \mathrm{c}$ & $1.9 \mathrm{bc}$ & $16.7 \mathrm{~cd}$ & $1.5 \mathrm{c}$ & 93 \\
\hline Koroneiki & CV F6-A17 R218 & Greece & $72.2 \mathrm{~cd}$ & $21.8 \mathrm{~cd}$ & $2.0 \mathrm{~b}$ & $25.0 \mathrm{~cd}$ & $1.6 \mathrm{bc}$ & 14 \\
\hline Sevillenca & CII F12-A13 R227 & Spain & $75.0 \mathrm{bcd}$ & $19.6 \mathrm{cde}$ & $1.8 \mathrm{bc}$ & $16.7 \mathrm{~cd}$ & $1.4 \mathrm{~cd}$ & 67 \\
\hline Frantoio & CV F6-A10 R80 & Italy & $72.2 \mathrm{~cd}$ & $15.0 \mathrm{cde}$ & $1.2 \mathrm{bcd}$ & $0.0 \mathrm{~d}$ & $2.1 \mathrm{a}$ & 66 \\
\hline Empeltre & CV F14-A19 R13 & Spain & $52.1 \mathrm{e}$ & $14.4 \mathrm{de}$ & $1.2 \mathrm{~cd}$ & $6.9 \mathrm{~cd}$ & $2.2 \mathrm{a}$ & 70 \\
\hline Changlot Real & CV F7-A21 R15 & Spain & $54.2 \mathrm{de}$ & $9.7 \mathrm{e}$ & $0.8 \mathrm{~d}$ & $8.3 \mathrm{~cd}$ & $2.0 \mathrm{ab}$ & 84 \\
\hline
\end{tabular}

${ }^{w}$ Plants were propagated from authenticated mother plants of olive cultivars from the Olive World Germplasm Bank (IFAPA, Centro Alameda del Obispo,

Córdoba, Spain). $\mathrm{CV}=$ reference of the field in the bank, $\mathrm{F}=$ row, $\mathrm{A}=$ tree, and $\mathrm{R}=$ accession number.

${ }^{\mathrm{x}}$ Disease parameters were evaluated periodically on the basis of a 0-to-4 rating scale during a period of 670 days after planting. DI $=$ final disease incidence;

RAUDPC $=$ relative area under the disease progress curve with reference to the maximum value potentially reached over the assessment period; FS $=$ final mean severity of symptoms; $\mathrm{M}=$ mortality. Values in columns followed by the same letter are not significantly different according to Fisher's protected least significant difference test at $P=0.05$.

${ }^{y}$ Olive growth was assessed on the basis of a 0-to-3 shoot length rating scale in October 2011 (1 year after planting). Values in columns followed by the same letter are not significantly different according to Kruskal Wallis test at $P=0.05$.

${ }^{\mathrm{z}}$ Percentage of diseased plant tissue affected by defoliation, calculated by the weighted average in the complete evaluation period. The rest of the diseased plant tissue was affected by sudden wilt.

Table 2. Values of disease parameters of major olive cultivars growing in a soil moderately infested with Verticillium dahliae (5 microsclerotia/g of soil) located in Andújar, Jaén province, southern Spain

\begin{tabular}{|c|c|c|c|c|c|c|c|c|}
\hline \multirow[b]{2}{*}{ Cultivar } & \multicolumn{2}{|c|}{ Olive cultivar ${ }^{w}$} & \multicolumn{4}{|c|}{ Disease parameters $^{x}$} & \multirow[b]{2}{*}{ Growth $^{y}$} & \multirow[b]{2}{*}{ Defol. $(\%)^{\mathrm{z}}$} \\
\hline & Reference & Origin & DI (\%) & RAUDPC (\%) & FS & M (\%) & & \\
\hline Cornicabra & CV F8-A16 R10 & Spain & $75 \mathrm{a}$ & $44.6 \mathrm{a}$ & $2.9 \mathrm{a}$ & $62.5 \mathrm{a}$ & $2.1 \mathrm{~d}$ & 76 \\
\hline Bodoquera & CV F10-A12 R361 & Spain & $62.5 \mathrm{ab}$ & $36.2 \mathrm{ab}$ & $2.3 \mathrm{ab}$ & $45.8 \mathrm{ab}$ & $2.5 \mathrm{bcd}$ & 62 \\
\hline Manzanilla de Sevilla & CV F1-A16 R1468 & Spain & $79.2 \mathrm{a}$ & $41.8 \mathrm{a}$ & $2.8 \mathrm{a}$ & $58.3 \mathrm{a}$ & $2.3 \mathrm{~cd}$ & 54 \\
\hline Picual & CV F3-A1 R1470 & Spain & $54.2 \mathrm{~b}$ & $23.2 \mathrm{bc}$ & $1.7 \mathrm{~b}$ & $33.3 \mathrm{~b}$ & $2.8 \mathrm{ab}$ & 25 \\
\hline Hojiblanca & CV F3-A11 R2 & Spain & $8.3 \mathrm{~d}$ & $8.5 \mathrm{~cd}$ & $0.3 \mathrm{c}$ & $8.3 \mathrm{c}$ & $2.7 \mathrm{abc}$ & 95 \\
\hline Arbequina & CV F2-A16 R1469 & Spain & $8.3 \mathrm{~d}$ & $6.2 \mathrm{~d}$ & $0.3 \mathrm{c}$ & $4.2 \mathrm{c}$ & $2.8 \mathrm{ab}$ & 100 \\
\hline Koroneiki & CV F6-A17 R218 & Greece & $33.3 \mathrm{c}$ & $9.3 \mathrm{~cd}$ & $0.4 \mathrm{c}$ & $0.0 \mathrm{c}$ & $2.8 \mathrm{ab}$ & 57 \\
\hline Sevillenca & CII F12-A13 R227 & Spain & $12.5 \mathrm{~d}$ & $2.3 \mathrm{~d}$ & $0.1 \mathrm{c}$ & $0.0 \mathrm{c}$ & $3.0 \mathrm{a}$ & 75 \\
\hline Frantoio & CV F6-A10 R80 & Italy & $8.3 \mathrm{~d}$ & $3.8 \mathrm{~d}$ & $0.2 \mathrm{c}$ & $0.0 \mathrm{c}$ & $2.9 \mathrm{ab}$ & 96 \\
\hline Empeltre & CV F14-A19 R13 & Spain & $4.2 \mathrm{~d}$ & $1.0 \mathrm{~d}$ & $0.1 \mathrm{c}$ & $0.0 \mathrm{c}$ & $2.7 \mathrm{abc}$ & 79 \\
\hline Changlot Real & CV F7-A21 R15 & Spain & $33.3 \mathrm{c}$ & $7.4 \mathrm{~d}$ & $0.4 \mathrm{c}$ & $0.0 \mathrm{c}$ & $3.0 \mathrm{a}$ & 71 \\
\hline
\end{tabular}

${ }^{w}$ Plants were propagated from authenticated mother plants of olive cultivars from the Olive World Germplasm Bank (IFAPA, Centro Alameda del Obispo, Córdoba, Spain). $\mathrm{CV}=$ Reference of the field in the bank, $\mathrm{F}=$ row, $\mathrm{A}=$ tree, $\mathrm{R}=$ accession number.

${ }^{x}$ Disease parameters were evaluated periodically on the basis of a 0-to- 4 rating scale during a period of 670 days after planting. DI $=$ final disease incidence; RAUDPCP = relative area under the disease progress curve with reference to the maximum value potentially reached over the assessment period; FS $=$ final mean severity of symptoms; $M=$ mortality. Values in columns followed by the same letter are not significantly different according to Fisher's protected least significant difference test at $P=0.05$

${ }^{y}$ Olive growth was assessed on the basis of a 0-to-3 shoot length rating scale in May 2011 (1 year after planting). Values in columns followed by the same letter are not significantly different according to Kruskal Wallis test at $P=0.05$.

${ }^{\mathrm{z}}$ Percentage of diseased plant tissue affected by defoliation, calculated by the weighted average in the complete evaluation period. The rest of the diseased plant tissue was affected by sudden wilt. 
are very similar but they differ mainly because of the Utrera milder winter temperatures.

The main characteristic considered for the selection of the two fields was the inoculum density (ID) of the pathogen in the soil. For assessing the fungal population in soil, about 40 to $50100-\mathrm{g}$ soil samples were collected from a depth of 25 to $30 \mathrm{~cm}$ using a cylindrical soil auger. Subsamples were mixed, bulked, and crumbled, then air dried for 3 weeks. Each sample was put through a $0.8-\mathrm{mm}$ sieve to remove organic debris and large particles, then mixed by hand and air dried for an additional week. Pathogen inoculum density was estimated by the wet sieving technique (24). Each sample $(25 \mathrm{~g})$ was suspended in $100 \mathrm{ml}$ of distilled water, shaken at $270 \mathrm{rpm}$ for $1 \mathrm{~h}$, and filtered through 150 - and $35-\mu \mathrm{m}$ sieves. The residue retained on the $35-\mu \mathrm{m}$ sieve was recovered in $100 \mathrm{ml}$ of distilled water. The suspension from each treatment (1 $\mathrm{ml}$ ) was plated on a modified sodium polipectate agar medium (11), using 10 replicated plates per treatment. After 14 days of incubation at $22 \pm 2{ }^{\circ} \mathrm{C}$ in the dark, soil residues were removed from the agar surface with tap water and colonies of $V$. dahliae were counted under a stereoscopic microscope. The ID in the soil sample was estimated by the number of colonies of $V$. dahliae and expressed as propagules or microsclerotia per gram of air-dried soil (MS/g). Finally, a highly infested plot (21 MS/g) and a moderately one $(5 \mathrm{MS} / \mathrm{g})$ were chosen to establish the olive orchards. Both fields had a clay-soil texture and had been cultivated the previous years with $V$. dahliae host species (mainly cotton). Additionally, ID was quantified, following the method described above, for each of the six blocks of each trial, in order to assess pathogen variation in the plots. Some isolates of $V$. dahliae were recovered from microsclerotia in the soil and were characterized for their virulent genotype by duplex, nested polymerase chain reaction (PCR) analysis (37).

Olive orchard establishment and experimental design. Olive trees were planted in the selected plots on 29 October 2009 (Utrera trial) and 14 April 2010 (Andújar trial). Tree spacing was 7 by 2.5 $\mathrm{m}$ in the Utrera trial and 5 by $2.5 \mathrm{~m}$ in the Andújar trial. In both experimental orchards, the trees were planted on ridges in order to avoid waterlogging and root infections caused by Phytophthora spp., which often causes a root rot disease of olive in this region (40). Experimental design was exactly the same in both trials. Plants of the 11 major cultivars were arranged in a randomized block design, with six blocks and four plants per block. Experimental fields were surrounded by olive trees of different cultivars planted together with the main plot. All plants were drip irrigated (15 liters/tree, 2 days/week, from April to October).

Assessment of symptom development and tree growth. Both experiments were surveyed periodically for symptom development and tree growth for 22 months after planting. Tree growth was assessed 1 year after planting, based on a 0 -to-3 visual rating scale, according to the number and length of new shoots $(0=$ no growth or 0.1 - to 5 -cm shoots in less than $50 \%$ of tree canopy, $1=0.1$ - to 5 -cm shoots in 51 to $100 \%$ of tree canopy or 5 - to $10-\mathrm{cm}$ shoots in 1 to $50 \%$ of tree canopy, $2=5$ - to $10-\mathrm{cm}$ shoots in 51 to $100 \%$ of tree canopy or more than $10-\mathrm{cm}$ shoots in 1 to $50 \%$ of tree canopy, and $3=$ more than $10-\mathrm{cm}$ shoots in 51 to $100 \%$ of tree canopy). To assess disease development, the percentage of diseased plant tissue, which was affected by each of the two types of VWO symptoms, was scored. These symptoms are defoliation and sudden wilt, which is characterized by the progressive rolling inward and chlorosis of leaves, which became necrotic and remained attached to the twigs. Estimates of disease incidence and severity were based on the percentage of affected plants and on a 0 -to- 4 rating scale according to the percentage of affected plant tissue with VWO symptoms $(0=$ no symptoms, $1=1$ to $33 \%, 2=34$ to $66 \%, 3=67$ to $99 \%$, and $4=$ dead plant), respectively (30). The percentage of dead plants or mortality (M) and the recovery from the disease were also considered in estimating the severity of the reactions $(27,30,45)$. At the end of each experiment, the relative area under the disease progress curve (RAUDPC) was estimated as the percentage with regard to the maximum potential value, for the period between the first symptom appearance and the end of the experiment, using the formula of Campbell and Madden (13):

$$
\text { RAUDPC }=\frac{100}{\left(s_{\max } \times t_{e}\right)} \times \sum_{i=1}^{n} \frac{\left(s_{i}+s_{i+1}\right)}{2} \times\left(t_{i+1}-t_{i}\right)
$$

where $s_{i}=$ disease severity value for observation number $i, s_{\max }=$ maximum value of severity (4), $t_{i}=$ number of days between planting and observation $i, t_{e}=$ total evaluation period, and $n=$ number of observations.

To compare the reaction of olive trees between both experimental fields, two disease development times in some cultivars were calculated by interpolation: $\mathrm{T}_{10}=$ time from planting until $10 \%$ of the trees were affected and $\mathrm{T}_{50}=$ time from planting until $50 \%$ of the trees were affected.

Pathogen isolation. Plant infection was confirmed by isolating the fungus from affected shoots or leaf petioles of diseased plants. Samples of affected woody tissue were washed in running tap water, the bark was removed, and tissue was surface disinfected in $0.5 \%$ sodium hypochlorite for $1 \mathrm{~min}$. Wood chips were placed on PDA plates and incubated at $24^{\circ} \mathrm{C}$ in the dark for 6 days. Isolates of $V$. dahliae recovered from affected olive plants were characterized for their virulence by duplex, nested PCR analysis (37).

Data analysis. For each field trial, individual analyses of variance of the evaluated parameters were performed using the Statistix 9.0 program (Analytical Software). Mean values of cultivars were compared by the Fisher's protected least significant difference test at $P=0.05$. Tree growth values were analyzed using the nonparametric Kruskal-Wallis test.

To determine whether there was interaction between field trials and cultivars, a combined analysis of variance was performed using the most representative disease parameter, RAUDPC, as the dependent variable. Data from the two individual trials were combined after checking with the $F$ test that the variances of the experimental error were homogeneous $(P=0.4005)$. Combined data were analyzed in a split-plot design with field trial as main plot and cultivar as subplot (21).

\section{Results}

Disease symptoms and pathogen isolation. Verticillium wilt symptoms were first observed in some susceptible cultivars 6 months after planting in both field trials. Disease development was more rapid in spring and fall when conditions for tree growth were optimal (Figs. 1 and 2). Symptoms which had started during the fall usually continued developing slowly in the winter, mainly in the Utrera trial. On the other hand, no new disease symptoms were observed between July and October (Figs. 1 and 2).

Defoliation and sudden wilt affected some branches or entire canopies in both experimental fields. Generally, both symptoms occurred together in a single tree. The mean percentage of diseased plant tissue affected by defoliation was 68 and 64\% (Utrera and Andújar trials, respectively; Tables 1 and 2) and changed little through the year. Defoliation and sudden wilt were generally severe in susceptible 'Bodoquera', Cornicabra, 'Manzanilla de Sevilla', and Picual. In most cases, infected trees were killed in a few months after the first symptoms appeared. Sometimes, this period was less than a month, particularly in the highly infested plot (Utrera trial).

Defoliation was less severe in shoots of moderately resistant cultivars, such as Changlot Real or Frantoio. However, severe defoliation and death of branches was also observed in some trees of these cultivars.

Disease symptoms developed differently depending on the cultivar (Tables 1 and 2). For example, diseased trees of 'Koroneiki' frequently exhibited sudden wilt symptoms which affected some branches, a portion of the tree, or the entire tree canopy. On the other hand, sudden wilt was rarely observed in Arbequina trees. In contrast, scattered defoliation of branches was frequently observed in the latter cultivar. 
The pathogen was recovered from nearly all affected shoots. All isolates recovered from symptomatic plants in both fields were identified as the defoliating pathotype (highly virulent isolates). $V$. dahliae isolates were recovered also from the soil. In both fields, more than $90 \%$ of isolates from soil were also found to be the defoliating pathotype.

Disease progress and tree growth. In the highly infested experimental field (Utrera trial), the number of plants that showed some of the disease symptoms described above during the 22month assessment period was very high in all cultivars, affecting at least $52 \%$ of the plants in each cultivar (Table 1). In the moderately infested field plot (Andújar trial), Verticillium wilt disease affected a lower number of plants with lower values of disease severity in all cultivars (Table 2).

Disease incidence reached values higher than 95\% (Utrera trial) and 50\% (Andújar trial) in the susceptible Cornicabra, Bodoquera, Manzanilla de Sevilla, and Picual. In these cultivars, almost all plants $(>91 \%)$ were killed by the pathogen during the assessment period in the highly infested plot, whereas mortality varied from 33 to $62 \%$ in the Andújar trial. Furthermore, disease onset was earlier and disease progress was faster in these susceptible cultivars than in the other cultivars in the two experimental fields (Figs. 1 and 2).

Cornicabra was extremely susceptible to Verticillium wilt and, in the 8 months after planting, $38 \%$ of the plants showed wilt symptoms and $13 \%$ had been killed by the pathogen in the Utrera experimental field. All plants of this cultivar were dead 20 months after planting. $\mathrm{T}_{10}$ calculated for Cornicabra was 6.5 months in the
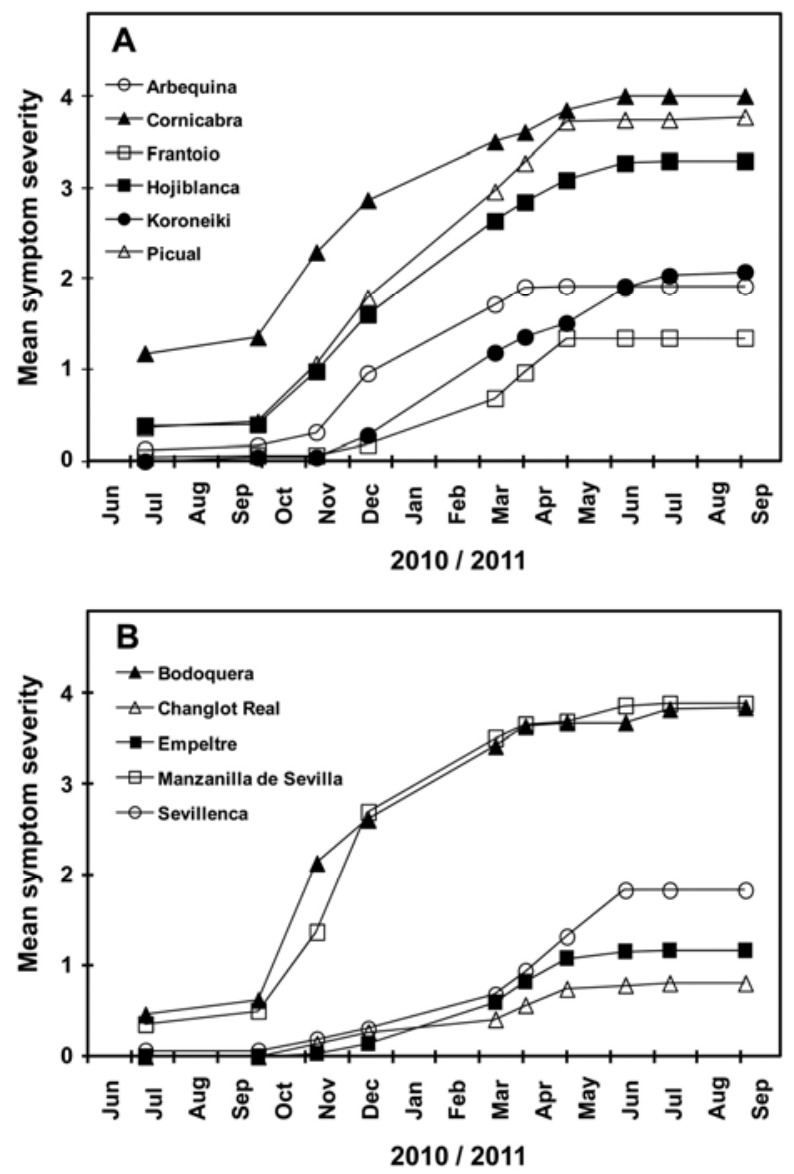

Fig. 1. A and B, Disease severity progress curves in olive cultivars grown in a soil highly infested with Verticillium dahliae (21 microsclerotia/g of soil), located in Utrera, Sevilla province, southern Spain. Assessments of disease severity were made periodically during 22 months after planting using a 0-to-4 rating scale according to percentage of plant tissue affected by defoliation and sudden wilt $(0=$ healthy plant or plant with no symptoms, $1=1$ to $33 \%, 2=34$ to $66 \%, 3=67$ to $99 \%$, and $4=$ dead plant). highly infested plot and 9.1 months in the moderately infested one. $\mathrm{T}_{50}$ was 11.2 and 12.7 months, respectively.

In both experimental orchards, Bodoquera, Manzanilla de Sevilla, and Picual showed a small delay in the onset and development of the disease compared with the extremely susceptible Cornicabra. This did not influence significantly the final values of severity of symptoms and the mortality of plants in both fields. The level of sensitivity exhibited by Hojiblanca was quite different between both fields. In the Utrera field, Hojiblanca was less susceptible compared with the susceptible group of cultivars (Table 1). Although many of them showed severe symptoms, $30 \%$ of the trees were still alive at the end of the experiment. This cultivar was more resistant in the Andújar field, with most of the disease values being similar to the values from resistant cultivars (Table 2). However, some trees of Hojiblanca were killed by $V$. dahliae, whereas virtually none of the resistant cultivars had died.

Disease responses observed in the other genotypes evaluated in the Utrera field were quite different and can be divided in two groups. The reaction of Arbequina, Koroneiki, and 'Sevillenca' was characterized by a high number of affected trees ( 72 to $83 \%$ ) that generally did not develop severe symptoms. In fact, final tree mortality did not exceed $25 \%$ of trees in any of these cultivars (Table 1). The most affected cultivar in this group was Arbequina, with a final value of RAUDPC close to $30 \%$. Both Koroneiki and Sevillenca showed similar disease parameters but with lower values of RAUDPC and disease incidence. Finally, Changlot Real, Empeltre, and Frantoio showed the most resistant reaction during the evaluation period, with RAUDPC values of 9.7 to $15 \%$ and final
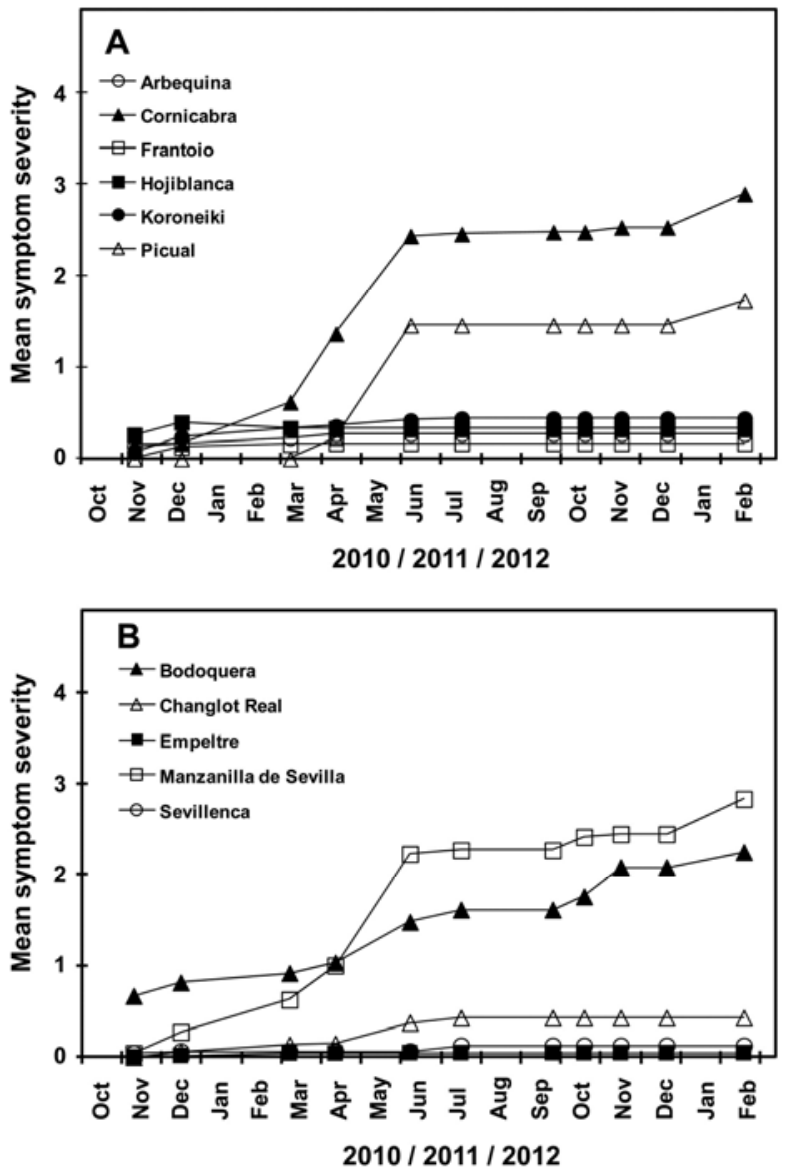

Fig. 2. A and B, Disease severity progress curves in olive cultivars grown in a soil moderately infested with Verticillium dahliae (5 microsclerotia/g of soil), located in Andújar, Jaén province, southern Spain. Assessments of disease severity were made periodically during 22 months after planting using a 0 -to-4 rating scale according to percentage of plant tissue affected by defoliation and sudden wilt $(0=$ healthy plant or plant with no symptoms, $1=1$ to $33 \%, 2=34$ to $66 \%, 3=67$ to $99 \%$, and 4 = dead plant). 
mean severity of 0.8 to 1.2 . Disease incidence was also high in this group but symptoms were slight in most cases and the pathogen did not kill any plants of Frantoio, and plant mortality was less than $10 \%$ in Changlot Real and Empeltre (Table 1).

The level of resistance was also corroborated by natural recovery observed in trees of cultivars which exhibited a more resistant reaction in both experimental fields. These plants were able to produce new vegetative shoots and leaves after they had suffered from slight or severe disease symptoms. This phenomenon, together with growth of nonsymptomatic plants, was assessed by the tree growth recorded at 12 months after planting, which corresponded to fall and spring, depending on the field (Tables 1 and 2).

The combined analysis of variance for RAUDPC showed that the three analyzed factors (field, cultivar, and field-cultivar interaction) were significant, with $P$ values of $0.0013,<0.0001$, and 0.0072 , respectively. The significance of the interaction was due to the differential response of two cultivars, Changlot Real and Hojiblanca (Fig. 3). Changlot Real had the same resistant response in both fields, whereas Hojiblanca was relatively more resistant in the Andújar than in the Utrera field. The remaining cultivars had a similar response in both fields, which was more severe in the Utrera field, with a higher inoculum density in the soil (Fig. 3).

\section{Discussion}

All of the olive genotypes in the current study have been repeatedly evaluated for $V$. dahliae resistance by artificial inoculation in growth chambers in a program that assesses $V$. dahliae resistance of olive genotypes deposited in the World Olive Germplasm Bank in Córdoba, Spain. This program, which was established in 1994 at the Department of Agronomy of the University of Córdoba, has used diverse inoculation methods, such as root-dipping or stem injection $(29,30,35)$. The levels of resistance or susceptibility previously obtained via artificial inoculation under controlled conditions were generally confirmed by the results of the current field study, in which olive cultivars were planted in two soils infested with defoliating pathotypes of $V$. dahliae. However, as discussed in the following paragraphs, there were some important differences in results obtained with artificial inoculation in the growth chamber versus natural inoculation in the field.

Cornicabra, Bodoquera, Manzanilla de Sevilla, and Picual were highly susceptible in both experimental fields, which is consistent with results previously obtained under controlled experiments, except in the case of Bodoquera $(29,30,35)$. This exception could

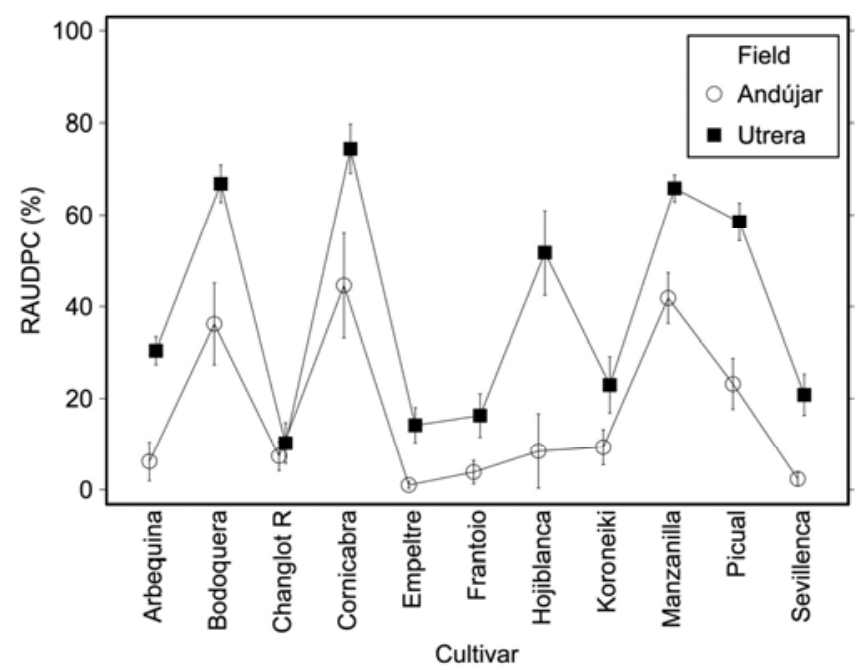

Fig. 3. Relative area under the disease progress curve (RAUDPC) in olive cultivars grown in two experimental fields infested with Verticillium dahliae: Andújar (moderately infested) and Utrera (highly infested). Disease severity was assessed periodically during 22 months after planting using a 0-to-4 rating scale according to percentage of plant tissue affected by defoliation and sudden wilt. Circles or squares are the mean of 24 plants, and vertical bars represent the standard error of the mean. be due to the inoculation method (trunk injection) that was used to assess the resistance of Bodoquera under controlled conditions. Bodoquera may be less sensitive when subjected to trunk injection than to natural infection in the field.

Cornicabra was most susceptible in both orchards. In the Utrera experimental orchard, Hojiblanca also was highly susceptible, which is consistent with previous results obtained under controlled conditions (30). In the Andújar orchard, however, Hojiblanca was more resistant compared with the other four susceptible cultivars, which is not consistent with results from controlled conditions but which is consistent with previous observations in commercial fields (31).

The disease reaction of Picual in both orchards was similar to that exhibited by this cultivar when artificially inoculated by root dipping $(30,35)$ and stem injection (29). Indeed, this cultivar is commonly used as a susceptible control and can be severely damaged by even a low amount of $V$. dahliae inoculum in the soil (28). Because Picual is by far the most widely grown olive cultivar in Spain (2), the high susceptibility of this cultivar to V. dahliae could be one reason why Verticillium wilt is presently a serious problem in southern Spain.

Arbequina, Koroneiki, and Sevillenca can be considered moderately resistant according to the results of the present study. Although disease resistance of these cultivars in the moderately infested soil was similar to that of Changlot Real, Empeltre, and Frantoio, the latter three cultivars were classified to be more resistant due to their disease reaction in the heavily infested soil.

Greek Koroneiki is considered to be moderately resistant to VWO based on experiments carried out in the field or under controlled conditions involving transplantation into artificially infested soil $(33,34)$, stem injection $(1,29)$, or root dipping $(35)$. The level of resistance in the present study was similar to that in these previous reports.

Presently, Arbequina is probably the most widely planted olive cultivar in the world (2), most likely because of its productivity and suitability for planting in hedgerows $(17,42)$. Arbequina was significantly more resistant than Picual in both orchards. Although this difference in resistance was previously observed in $V$. dahliaeinfested soil, both cultivars were considered to be highly susceptible when assessed under controlled conditions using a conidial suspension $\left(10^{7}\right.$ conidia/ml $)$ of the defoliating pathotype of $V$. dahliae $(30,35)$. We believe that this difference is probably related to a threshold pathogen inoculum potential above which the resistance of a given cultivar is completely overcome. Although resistant in the field with moderate disease pressure, resistance of Picual and Arbequina may be overcome by the high inoculum density typically used in artificial inoculations. The superior field performance of Arbequina is supported by studies showing reduced ability of $V$. dahliae to colonize Arbequina compared with Picual (36).

The level of resistance exhibited by Sevillenca was greater in the current study than in a previous study, in which the cultivar was artificially inoculated with the defoliating pathotype of $V$. dahliae (35). As mentioned for Arbequina in the previous paragraph, the resistance of Sevillenca would probably be completely overcome by the high inoculum density used in artificial inoculations.

Among the cultivars in this study, Spanish Changlot Real and Empeltre together with Italian Frantoio were the most resistant to VWO and generally showed only minor disease symptoms in both experimental orchards. The heavily infested plot allowed us to differentiate between the resistance of these cultivars and that of other moderately resistant cultivars such as Arbequina, Koroneiki, and Sevillenca. In artificial inoculations, Changlot Real, Empeltre, and Frantoio usually exhibited complete resistant to VWO. Moreover, the response of Frantoio to Verticillium wilt has been well documented under controlled and field conditions (4,10,29-31,35). However, these three cultivars did not exhibit complete resistance when they were planted in a soil that was heavily infested with $V$. dahliae in the current field study, and their use as resistant cultivars or rootstocks in heavily infested soils should be carefully consid- 
ered. Because Changlot Real, in particular, but also Empeltre and Frantoio have acceptable agronomic characteristics $(2,39)$, they are the best choice for new olive plantings in $V$. dahliae-infested soils. These three genotypes are also being used in a breeding program for Verticillium wilt resistance in olive (43).

The ranking of cultivars according to disease parameters was similar in both orchards. According to $\mathrm{T}_{10}$ and $\mathrm{T}_{50}$ values, disease developed more quickly and was more severe in the Utrera orchard than in the Andújar orchard. This was true for all cultivars in the study and was expected because the $V$. dahliae inoculum density was higher in the Utrera orchard (21 MS/g of soil) than in the Andújar orchard (5 MS/g of soil). This difference between the orchards agrees with previous research conducted in the field $(7,28)$. Higher winter temperatures in the Utrera orchard than in the Andújar orchard may also have contributed to the higher disease severity in the Utrera orchard (31). These results indicate that the level of inoculum in the soil should be determined when olive cultivars are evaluated for resistance to V. dahliae.

The differences between the two experimental orchards were highlighted by the combined analysis of variance. However, this analysis revealed a significant interaction between cultivars and fields due to the differential responses of Changlot Real and Hojiblanca. This interaction was especially marked in Hojiblanca, which was ranked with the susceptible cultivars in the Utrera orchard but with the moderately resistant cultivars in the Andújar orchard.

Disease incidence does not seem to be a sufficiently sensitive parameter for assessing VWO resistance in the field, particularly in heavily infested sites. In the heavily infested Utrera orchard, every affected tree belonging to a susceptible cultivar was killed or severely damaged by the pathogen, whereas affected trees of resistant cultivars usually developed mild symptoms and then recovered from the disease. Although mortality (the percentage of dead plants) is easy to measure, it was similar to disease incidence in being insufficiently sensitive for detecting moderate differences in resistance. The other disease parameters assessed helped differentiate the reactions of olive cultivars to the disease, and RAUDPC and final severity 22 months after planting were especially useful. These two parameters were also highly correlated (data not shown). Tree growth, which is not usually considered in evaluating disease resistance under controlled conditions, also differentiated among levels of resistance.

Defoliation and sudden wilt were frequently observed together in a single tree from fall to late spring in our study. Moreover, the $V$. dahliae defoliating pathotype caused both symptoms. These observations are contrary to those previously reported $(31,38)$. In the current study, the type of symptom differed depending on the cultivar, suggesting that different mechanisms of resistance could be involved.

This study has clearly demonstrated that Verticillium wilt is a serious threat in olive orchards that are moderately or heavily infested with $V$. dahliae. Heavily infested soils occur in many areas where hosts of $V$. dahliae have been cultivated for many years, such as in the Central Valley in California and the Guadalquivir Valley in Andalucía, Spain, where this study was carried out. Although both regions are irrigated and have excellent environmental conditions for growing olive trees $(3,45)$, the defoliating pathotype of $V$. dahliae is widespread and heavily infests the soil in some areas of these regions $(6,18,32,44)$, which makes the growing of olive trees a challenge. Thus, farmers should be warned about the planting of olive trees in infested soil and should be advised against growing susceptible cultivars in such soils. As indicated in the present study and other published research (31), complete field resistance has not been found in olive to date; thus, there is no cultivar that can be recommended in areas with high disease pressure. Therefore, research aimed at identifying olive cultivars with field resistance to Verticillium wilt should be continued. Nevertheless, some of the cultivars evaluated in this study can help growers control the disease in areas with moderate pathogen levels in the soil.

\section{Acknowledgments}

This research was partially funded by the Projects AGL2007-65766 (Spanish Ministerio de Ciencia e Innovación, co-financed by FEDER of the EU), P08AGR-03635 (Junta de Andalucía, Spain), "Transforma Olivar y Frutos Secos" (Junta de Andalucía, Spain), and 2009-00008 (FEDER-INIA). We thank J. Mercado-Blanco (IAS-CSIC, Córdoba) for characterizing the pathotype of $V$. dahliae isolates from infected plants; W. Kaiser for critical review of the manuscript; and the Oficina Comarcal Agraria "Las Marismas" (Lebrija, Sevilla), the Sociedad Cooperativa Andaluza "Agroquivir" (Trajano, Sevilla), the Oficina Comarcal "Sierra Morena/Campiña Jaén" (Andújar, Jaén), the Comunidad de Regantes "Ntra. Sra. de los Dolores" (Arjona, Jaén), and R. Jiménez del Río for their essential participation, permitting the authors to conduct experiments on their property, and their technical assistance.

\section{Literature Cited}

1. Antoniou, P. P., Markakis, E. A., Tjamos, S. E., Paplomatas, E. J., and Tjamos, E. C. 2008. Novel methodologies in screening and selecting olive varieties and root-stocks for resistance to Verticillium dahliae. Eur. J. Plant Pathol. 122:549-560.

2. Barranco, D. 2010. Varieties and rootstocks. Pages 59-82 in: Olive Growing. D. Barranco, R. Fernández-Escobar, and L. Rallo, eds. Junta de Andalucía/Mundi Prensa/RIRDC/AOA, Pendle Hill, Australia.

3. Barranco, D., Fernández-Escobar, R., and Rallo, L. 2010. Olive Growing. Junta de Andalucía/Mundi Prensa/RIRDC/AOA, Pendle Hill, Australia.

4. Barranco, D., and Trujillo, I. 2000. Are 'Oblonga' and 'Frantoio' olives the same cultivar? HortScience 35:1323-1325.

5. Bartolini, G., Petruccelli, R., Tindall, H. D., and Menini, U. G. 2002. Classification, Origin, Diffusion and History of the Olive. FAO, Rome.

6. Bejarano-Alcazar, J., Blanco-Lopez, M. A., Melero-Vara, J. M., and Jimenez-Diaz, R. M. 1996. Etiology, importance, and distribution of Verticillium wilt of cotton in southern Spain. Plant Dis. 80:1233-1238.

7. Bejarano-Alcazar, J., Melero-Vara, J. M., Blanco-Lopez, M. A., and Jimenez-Diaz, R. M. 1995. Influence of inoculum density of defoliating and nondefoliating pathotypes of Verticillium dahliae on epidemics of Verticillium wilt of cotton in southern Spain. Phytopathology 85:1474-1481.

8. Blanco-López, M. A., Hiemstra, J. A., Harris, D. C., López-Escudero, F. J., and Antoniou, P. 1998. Selection and screening for host resistance. Pages 51-54 in: Compendium of Verticillium Wilt in Trees Species. J. A. Hiemstra and D. C. Harris, eds. Ponsen \& Looijen, Wageningen, The Netherlands.

9. Blanco-López, M. A., Jiménez-Díaz, R. M., and Caballero, J. M. 1984. Symptomatology, incidence and distribution of Verticillium wilt of olive tree in Andalucía. Phytopathol. Mediterr. 23:1-8.

10. Bubici, G., and Cirulli, M. 2012. Control of Verticillium wilt of olive by resistant rootstocks. Plant Soil 352:363-376.

11. Butterfield, E. J., and Devay, J. E. 1977. Reassessment of soil assays for Verticillium dahliae. Phytopathology 67:1073-1078.

12. Caballero, J. M., and Del Río, C. 2010. Propagation methods. Pages 83-112 in: Olive Growing. D. Barranco, R. Fernández-Escobar, and L. Rallo, eds. Junta de Andalucía/Mundi Prensa/RIRDC/AOA, Pendle Hill, Australia.

13. Campbell, C. L., and Madden, L. V. 1990. Introduction to Plant Disease Epidemiology. John Wiley and Sons, New York.

14. Cirulli, M., Colella, C., D'Arnico, M., Amenduni, M., and Bubici, G. 2008. Comparison of screening methods for the evaluation of olive resistance to Verticillium dahliae Kleb. J. Plant Pathol. 90:7-14.

15. Cirulli, M., and Montemurro, G. 1976. A comparison of pathogenic isolates of Verticillium dahliae and sources of resistance in olive. Agric. Conspectus Sci. 39:469-476.

16. Colella, C., Miacola, C., Amenduni, M., D’Amico, M., Bubici, G., and Cirulli, M. 2008. Sources of Verticillium wilt resistance in wild olive germplasm from the Mediterranean region. Plant Pathol. 57:533-539.

17. De la Rosa, R., Leon, L., Guerrero, N., Rallo, L., and Barranco, D. 2007. Preliminary results of an olive cultivar trial at high density. Aust. J. Agric. Res. 58:392-395.

18. Epstein, L., Beede, R., Kaur, S., and Ferguson, L. 2004. Rootstock effects on pistachio trees grown in Verticillium dahliae-infested soil. Phytopathology $94: 388-395$.

19. Erten, L., and Yildiz, M. 2011. Screening for resistance of Turkish olive cultivars and clonal rootstocks to Verticillium wilt. Phytoparasitica 39:8392.

20. FAO. 2010. The Statistical Database (FAOSTAT). Rome. http://faostat. fao.org

21. Gomez, K. A., and Gomez, A. A. 1984. Statistical Procedures for Agricultural Research, 2nd ed. John Wiley and Sons, New York.

22. Haouane, H., El Bakkali, A., Moukhli, A., Tollon, C., Santoni, S., Oukabli, A., El Modafar, C., and Khadari, B. 2011. Genetic structure and core collection of the World Olive Germplasm Bank of Marrakech: towards the optimised management and use of Mediterranean olive genetic resources. Genetica 139:1083-1094.

23. Hiemstra, J. A., and Harris, D. C. 1998. A Compendium of Verticillium Wilt in Tree Species. Ponsen \& Looijen, Wageningen, The Netherlands.

24. Huisman, O. C., and Ashworth, L. J. 1974. Verticillium albo-atrum quantitative isolation of microsclerotia from field soils: procedural and substrate improvements. Phytopathology 64:1159-1163. 
25. Jiménez-Díaz, R. M., Olivares-García, C., Landa, B. B., Del Mar JiménezGasco, M., and Navas-Cortés, J. A. 2011. Region-wide analysis of genetic diversity in Verticillium dahliae populations infecting olive in Southern Spain and agricultural factors influencing the distribution and prevalence of vegetative compatibility groups and pathotypes. Phytopathology 101:304-315.

26. Lopez-Escudero, F. J., and Blanco-Lopez, M. A. 2001. Effect of a single or double soil solarization to control Verticillium wilt in established olive orchards in Spain. Plant Dis. 85:489-496.

27. López-Escudero, F. J., and Blanco-López, M. A. 2005. Recovery of young olive trees from Verticillium dahliae. Eur. J. Plant Pathol. 113:367-375.

28. López-Escudero, F. J., and Blanco-López, M. A. 2007. Relationship between the inoculum density of Verticillium dahliae and the progress of Verticillium wilt of olive. Plant Dis. 91:1372-1378.

29. López-Escudero, F. J., Blanco-López, M. A., Del Río Rincón, C., and Caballero Reig, J. M. 2007. Response of olive cultivars to stem puncture inoculation with a defoliating pathotype of Verticillium dahliae. HortScience 42:294-298.

30. López-Escudero, F. J., Del Río, C., Caballero, J. M., and Blanco-López, M. A. 2004. Evaluation of olive cultivars for resistance to Verticillium dahliae. Eur. J. Plant Pathol. 110:79-85.

31. López-Escudero, F. J., and Mercado-Blanco, J. 2011. Verticillium wilt of olive: a case study to implement an integrated strategy to control a soilborne pathogen. Plant Soil 344:1-50.

32. López-Escudero, F. J., Mercado-Blanco, J., Roca, J. M., Valverde-Corredor, A., and Blanco-López, M. A. 2010. Verticillium wilt of olive in the Guadalquivir valley (southern Spain): relations with some agronomical factors and spread of Verticillium dahliae. Phytopathol. Mediterr. 49:370-380.

33. Markakis, E. A., Tjamos, S. E., Antoniou, P. P., Paplomatas, E. J., and Tjamos, E. C. 2009. Symptom development, pathogen isolation and RealTime QPCR quantification as factors for evaluating the resistance of olive cultivars to Verticillium pathotypes. Eur. J. Plant Pathol. 124:603-611.

34. Markakis, E. A., Tjamos, S. E., Antoniou, P. P., Roussos, P. A., Paplomatas, E. J., and Tjamos, E. C. 2010. Phenolic responses of resistant and susceptible olive cultivars induced by defoliating and nondefoliating Verticillium dahliae pathotypes. Plant Dis. 94:1156-1162.
35. Martos-Moreno, C., López-Escudero, F. J., and Blanco-López, M. Á. 2006. Resistance of olive cultivars to the defoliating pathotype of Verticillium dahliae. HortScience 41:1313-1316.

36. Mercado-Blanco, J., Collado-Romero, M., Parrilla-Araujo, S., RodríguezJurado, D., and Jiménez-Díaz, R. M. 2003. Quantitative monitoring of colonization of olive genotypes by Verticillium dahliae pathotypes with real-time polymerase chain reaction. Physiol. Mol. Plant Pathol. 63:91-105.

37. Mercado-Blanco, J., Rodríguez-Jurado, D., Parrilla-Araujo, S., and Jiménez-Díaz, R. M. 2003. Simultaneous detection of the defoliating and nondefoliating Verticillium dahliae pathotypes in infected olive plants by duplex, nested polymerase chain reaction. Plant Dis. 87:1487-1494.

38. Navas-Cortés, J. A., Landa, B. B., Mercado-Blanco, J., Trapero-Casas, J. L. Rodríguez-Jurado, D., and Jiménez-Díaz, R. M. 2008. Spatiotemporal analysis of spread of infections by Verticillium dahliae pathotypes within a high tree density olive orchard in Southern Spain. Phytopathology 98:167180.

39. Rallo, L., Barranco, D., Caballero, J. M., Del Río, C., Martín, A., Tous, J., and Trujillo, I. 2005. Variedades de olivo en España. Junta de Andalucía/MAPA/Mundi-Prensa, Madrid.

40. Sánchez Hernández, M. E., Ruiz Dávila, A., Pérez De Algaba, A., Blanco López, M. A., and Trapero Casas, A. 1998. Occurrence and etiology of death of young olive trees in southern Spain. Eur. J. Plant Pathol. 104:347 357.

41. Thanassoulopoulos, C. C., Biris, D. A., and Tjamos, E. C. 1979. Survey of Verticillium wilt of olive trees in Greece. Plant Dis. Rep. 63:936-940.

42. Tous, J., Romero, A., Plana, J., and Hermoso, J. F. 2008. Olive oil cultivars suitable for very-high density planting conditions. Acta Hortic. 791:403 408.

43. Trapero, C., Muñoz-Díez, C., Rallo, L., López-Escudero, F. J., and Barranco, D. 2011. Screening olive progenies for resistance to Verticillium dahliae. Acta Hortic. 924:137-140.

44. Wilhelm, S., Opitz, K. W., Kaiser, W. J., and Georgopoulos, S. G. 1962 Verticillium wilt of olives in California. (Abstr.) Phytopathology 52:32.

45. Wilhelm, S., and Taylor, J. B. 1965. Control of Verticillium wilt of olive through natural recovery and resistance. Phytopathology 55:310-316. 